\title{
Systematics and Conservation of Neotropical Amphibians and Reptiles
}

\author{
Alessandro Catenazzi ${ }^{1, *(D)}$ and Rudolf von May ${ }^{2}$ (D) \\ 1 Department of Biological Sciences, Florida International University, 11200 SW 8th Street, \\ Miami, FL 33199, USA \\ 2 Biology Program, California State University Channel Islands, 1 University Dr., Camarillo, CA 93012, USA; \\ rudolf.vonmay@csuci.edu \\ * Correspondence: alessandro.catenazzi1@fiu.edu or acatenazzi@gmail.com
}

Citation: Catenazzi, A.; von May, R. Systematics and Conservation of Neotropical Amphibians and Reptiles. Diversity 2021, 13, 45. https:// doi.org/10.3390/d13020045

Received: 14 January 2021

Accepted: 18 January 2021

Published: 25 January 2021

Publisher's Note: MDPI stays neutral with regard to jurisdictional claims in published maps and institutional affiliations.

Copyright: (c) 2021 by the authors. Licensee MDPI, Basel, Switzerland. This article is an open access article distributed under the terms and conditions of the Creative Commons Attribution (CC BY) license (https:// creativecommons.org/licenses/by/ $4.0 /)$.
The Neotropics host an exuberant diversity of life forms, including amphibians and reptiles. This diversity is partially unknown. Systematic and taxonomic studies are essential for conservation, because we can only preserve what we know. The first step in documenting biodiversity is to identify species and to name and organize them according to their evolutionary history. The number of species of amphibians and reptiles has increased sharply over the last few decades, but we have much work ahead of us if we want to describe the outstanding biodiversity of the Neotropical herpetofauna. At the same time, traditional and emergent threats are accelerating the erosion of herpetofaunal biodiversity. Traditional threats include habitat loss such as deforestation, wetland drainage, grassland fires, overuse of fertilizers and pesticides, and over-harvesting of wild populations. Emerging threats such as disease and climate change affect species within natural protected areas, where habitat loss and fragmentation may be negligible. Emerging infectious diseases, such as chytridiomycosis, are associated with population decline and the collapse of amphibian communities throughout the Neotropics. Additionally, while climate change threatens many amphibian and reptile species, it remains unclear how species will cope with increasing temperatures, seasonal shifts, and increasing frequency of extreme climatic events. This apparent paradox of species gains in science (i.e., newly named species) amid species loss and population declines is a key element of this special issue.

The endeavor of the special issue was to gather original studies aimed at improving the knowledge of systematics, taxonomy, and conservation of Neotropical amphibians and/or reptiles. We welcomed contributions that examined the evolutionary relationships and geographic distributions of selected Neotropical taxa, helped resolve standing taxonomic issues, and recognized, described, and named new species. We encouraged papers proposing new methods to accelerate taxonomic studies, including those that presented novel molecular techniques. Finally, we welcomed submissions from applied conservation, covering a variety of topics ranging from methods to identify priority areas for conservation and reserve design, to policymaking and assessments of species threat status.

Our issue was very inclusive in terms of welcoming articles from the "core" Neotropical region, but also from adjacent regions. Philip L. Sclater [1] defined the Neotropical region as encompassing central and southern Mexico, Central America, the Caribbean Islands, and South America. Alfred R. Wallace [2] recognized four sub-regions within the Neotropics, based on the distribution and taxonomic relationships of vertebrates. In recent decades, some researchers have redefined the Neotropics on the basis of phylogenetic analyses and geographic range maps [3]. However, not all researchers agree with the updated classification [4]. Some of the most recent analyses recognize the original extent of the Neotropical region, but they exclude the southwestern tip of South America [5-7] (Figure 1). All these classifications can prove useful in explaining patterns of species diversity, diversification, and biotic interchange within the Neotropics. 
We are very pleased to present a special issue containing 14 articles that encompass three broad areas: systematics, biogeography, and conservation. The articles cover frogs, salamanders, caecilians, lizards, and snakes from throughout the Neotropics, with specific studies from Mexico, Costa Rica, Panama, Colombia, Ecuador, Peru, Paraguay, and Brazil. Authors in this special issue named a new genus of frogs (Qosqophryne), four new species of frogs (one terrestrial-breeding frog and three glassfrogs), and five new lizards (three tropidurid and two gymhnophthalmid lizards). A monograph on glassfrogs of Ecuador spans the three thematic areas. Among contributions on biogeography, approaches ranged from species distribution patterns to the use of barcoding at the country level, phylogenomic analyses using ultraconserved elements, and island biology. The remaining studies explored current conservation issues, examining the impact of mining, fungal disease, and the conservation implications of endemism.

The contributions on taxonomy and systematics focus on the Peruvian Andes, a region of exceptional herpetological species richness. The rate of species descriptions for Peru, similar to other mountainous tropical countries, is among the highest for frogs and lizards. The special issue includes a new genus name, for a group of terrestrial-breeding frogs (Strabomantidae). Molecular phylogenetic analyses of three species previously assigned to Bryophryne, in addition to bioacoustics and some morphological traits, support the erection of the new genus Qosqophryne [8], honoring the region around the city of Cuzco where these frogs are endemic. Santa-Cruz et al. [9] name a related terrestrial-breeding frog in the genus Noblella with a distribution extending from the lowlands of southwestern Amazonia to the Andean cloud forests across several protected areas. Aguilar-Puntriano et al. [10] describe three new species of Liolaemus (Tropiduridae) from the Pacific coast and the High Andes. Mamani et al. [11] name a new species of Cercosaura (Gymnophthalmidae) from a montane forest in central Peru and resolve the taxonomy of Cercosaura anomala. Additionally, Mamani et al. hint at the possibility of a new genus for the enigmatic Cercosaura manicata boliviana, which is more closely related to the clade containing all known Potamites species than to other Cercosaura species [11].

Two other contributions on frog systematics cover wider geographical areas and discuss family-level relationships. Guillory et al. [12] use genomic data from the flanking regions of ultraconserved elements to generate a phylogeny of Neotropical poison frogs (Dendrobatidae). Neotropical poison frogs are famous for their aposematic coloration and associated toxicity, which stimulated curiosity and spurred many investigations on the evolution of skin defenses and coloration [13-15]. Although Guillory et al.'s findings confirm previous phylogenies inferred from combining few mitochondrial and nuclear gene fragments, their approach reveals much potential for scalable genomic techniques that can be applied to help solve conservation problems related to loss of genetic diversity.

Guayasamin et al. [16] offer a superb monograph on all Ecuadorian glassfrogs, covering the taxonomy, morphology, phylogenetic relationships, ecology, and natural history of one of the most charismatic group of frogs. In addition to representing the bulk of this book and special issue, this contribution has all the qualities to become a classic work for people interested in the biology and evolution of glassfrogs. The family Centrolenidae is turning into an excellent model system for studies on parental care, diversification, and evolution [17-20]. Guayasamin et al. [16] provide species accounts for each of the 60 species known from Ecuador, including photographs of living and preserved frogs, drawings, distribution range maps, ecology, and conservation status. Last but not the least, these authors also describe three new species in the genus Nymphargus, two of which honor the amphibian biologists Linda Trueb and Luis Coloma [16].

Biogeography is a common thread among five contributions, one on frogs and four on squamates. Ramírez et al. [21] examine the radiation of the highly threatened harlequin frogs (Atelopus) into Central America. Their model-based ancestral area estimation supports one or two colonization events from South America. Molecular clock analyses of divergence times suggest that these events occurred prior to 4 million years ago, a slightly older than traditional date for the closure of the Isthmus [21]. In contrast to harlequin frogs and 
other amphibians, which benefited from early efforts at categorizing their distribution in the context of the Global Amphibian Assessment and IUCN Red List of Threatened Species [22], squamate global threat assessments have experienced a later start, despite studies suggesting a high proportion of threatened species [23]. Therefore, articles in this issue will contribute to ongoing efforts to develop a clear picture of global squamate biodiversity patterns and conservation. As is true for amphibians, it is likely that cryptic species abound among squamates, exposing the benefits of barcoding approaches that can quickly reveal candidate new species and approximate genetic diversity in complexes of cryptic species. Cacciali et al. [24] present the first barcoding analysis of Paraguayan squamates, using sequences of the $16 \mathrm{~S}$ rRNA mitochondrial gene for 63 native and one introduced species. Although the authors did not sample all species and geographic areas, the study is a first important step in building datasets of molecular genetics that can ameliorate the challenges of taxonomy and conservation. Taxonomic uncertainty, when compounded with low sampling and collecting efforts and rarity, can produce imprecise, if not intriguing, biodiversity patterns. Rabosky et al. [25] discuss one such pattern related to lower species richness of snakes and lizard in southwestern Amazonia compared with northwestern Amazonia. They quantify the reduction at 25\% compared to western equatorial sites and discuss some possible mechanisms for the equatorial to southwestern Amazonia species richness gradient, such as cycles of expansion and contraction of savannah habitats in southwestern Amazonia resulting in the loss of some species [25]. Snake encounters are notoriously serendipitous, and in tropical areas with high species richness, compiling ecological data can take decades. Birskis-Barros et al. [26] contribute natural history information important for conserving pit vipers (Crotalinae), in the Americas. Although most pit vipers have large geographical ranges and narrow habitat breadths, about one tenth of the known species are rare and occur along the Pacific coast of Mexico, in southern Central America, in the Andean region of Ecuador, and in eastern Brazil, driving the inverse correlation between abundance and latitude. Finally, Phillips et al. [27] examine the systematics and ecomorphology of four species of Pacific Island anoles. Anoles are a staple of Caribbean biology and biogeography studies, but much less is known about Pacific Island anoles. The two species from Isla Malpelo and Isla Cocos diverged from mainland ancestors prior to the emergence of their respective islands and, similar to single-island endemic Caribbean anoles, appear to display sexual size dimorphism [27].

Three articles on conservation biology are representative of current challenges in assessing the conservation status of often discreet animals, including possible causes of population declines and local extinctions. The cover of the online special issue illustrates the article discussing conservation implications for enzootic chytridiomycosis, the "covid of frogs," for Costa Rican amphibians [28]. Chytridiomycosis is implicated in the decline of at least 501 species of amphibians worldwide [29]. In this issue, Zumbado-Ulate et al. [28] give an overview of the disease in Costa Rica, where epizootic mass die-offs and declines occurred in the 1980s and 1990s. The chytrid fungus is now common across the country, especially in the Caribbean lowlands and among amphibians with aquatic larvae. Infection loads are generally below theoretical thresholds associated with mortality and highest in direct-developing species [28]. Bornschein et al. [30] discuss the conservation status of the minute but fascinating Brachycephalus frogs of the Brazilian Atlantic forest. Several species of Brachycephalus suffered population declines or have not been seen in several decades, despite the number of new species continuing to climb. An increasing threat to herpetofauna in many Neotropical countries, the impact of mining and associated habitat loss is discussed for the endemic herpetofauna of Mexico [31]. Mayani-Parás et al. [24] examine the impact of habitat loss and mining activities on potential distributions from ecological niche models of 179 Mexican endemic herpetofaunal species. The daunting conclusion is that the combined effect of habitat loss and mining may exert stronger impacts on extant species distribution than habitat loss alone. 


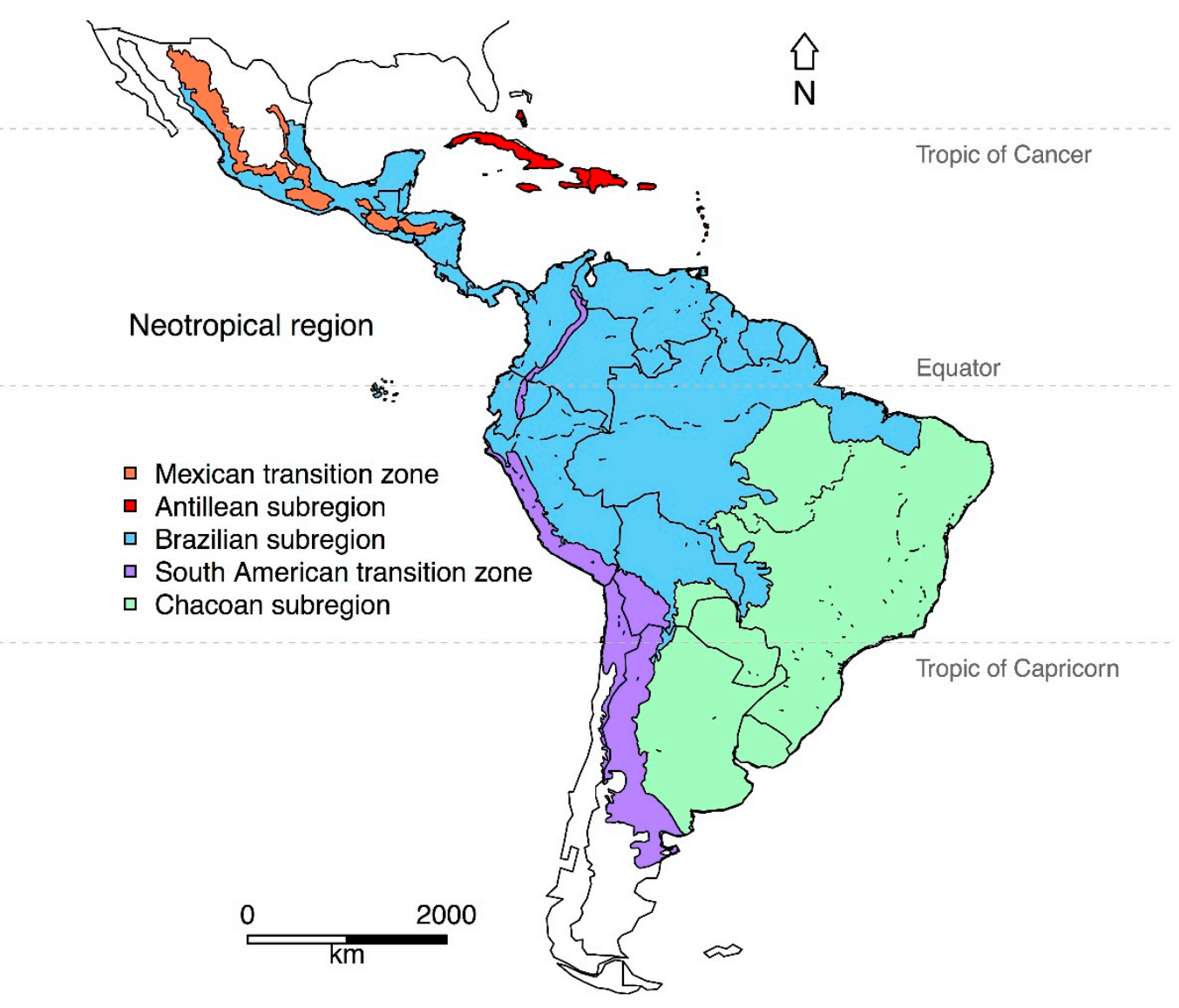

Figure 1. Map of the Neotropical region depicting the transition zones/sub-regions according to the regionalization by Morrone (2014) [6]. Shapefiles downloaded from www.neotropico.com.br/shapefile [32].

We hope this publication will serve multiple functions. It will serve as a field book helping to identify glassfrogs in Ecuador and support species conservation status assessment and design of protected areas. We are optimistic that the book will stimulate more research on the Neotropical herpetofauna and provide strong foundations for proposing or refining hypotheses elucidating its exceptional beauty and diversity.

Funding: This research received no external funding.

Acknowledgments: We thank S. Kupferberg for comments on a draft of the manuscript.

Conflicts of Interest: This research received no external funding.

\section{References}

1. Sclater, P.L. On the general geographic distribution of the members of the class Aves. Zool. J. Linn. Soc. 1858, 2, 130-145. [CrossRef]

2. Wallace, A.R. The Geographical Distribution of Animals; Harper and Brothers: New York, NY, USA, 1876; Volumes I \& II.

3. Holt, B.; Lessard, J.P.; Borregaard, M.K.; Fritz, S.A.; Araujo, M.B.; Dimitrov, D.; Fabre, P.H.; Graham, C.H.; Graves, G.R.; Jonsson, K.A.; et al. An update of Wallace's zoogeographic regions of the World. Science 2013, 339, 74-78. [CrossRef]

4. Kreft, H.; Jetz, W. Comment on “An update of Wallace's zoogeographic regions of the World”. Science 2013, 341, 343. [CrossRef] [PubMed]

5. Antonelli, A.; Zizka, A.; Carvalho, F.A.; Scharn, R.; Bacon, C.D.; Silvestro, D.; Condamine, F.L. Amazonia is the primary source of Neotropical biodiversity. Proc. Natl. Acad. Sci. USA 2018, 115, 6034-6039. [CrossRef] [PubMed]

6. Morrone, J.J. Biogeographical regionalisation of the Neotropical region. Zootaxa 2014, 3782, 1-110. [CrossRef] [PubMed]

7. Olson, D.M.; Dinerstein, E.; Wikramanayake, E.D.; Burgess, N.D.; Powell, G.V.N.; Underwood, E.C.; D'Amico, J.A.; Itoua, I.; Strand, H.E.; Morrison, J.C.; et al. Terrestrial ecoregions of the worlds: A new map of life on Earth. Bioscience 2001, 51, 933-938. [CrossRef]

8. Catenazzi, A.; Mamani, L.; Lehr, E.; von May, R. A new genus of terrestrial-breeding frogs (Holoadeninae, Strabomantidae, Terrarana) from southern Peru. Diversity 2020, 12, 184. [CrossRef] 
9. Santa-Cruz, R.; von May, R.; Catenazzi, A.; Whitcher, C.; Tejeda, E.L.; Rabosky, D.L. A new species of terrestrial-breeding frog (Amphibia, Strabomantidae, Noblella) from the upper Madre de Dios watershed, Amazonian Andes and lowlands of southern Peru. Diversity 2019, 11, 145. [CrossRef]

10. Aguilar-Puntriano, C.; Ramírez, C.; Castillo, E.; Mendoza, A.; Vargas, V.J.; Sites, J.W. Three new lizard species of the Liolaemus montanus Group from Peru. Diversity 2019, 11, 161. [CrossRef]

11. Mamani, L.; Chaparro, J.C.; Correa, C.; Alarcón, C.; Salas, C.Y.; Catenazzi, A. A new species of Andean gymnophthalmid lizard (Squamata: Gymnophthalmidae) from the Peruvian Andes, and resolution of some taxonomic problems. Diversity 2020, 12, 361. [CrossRef]

12. Guillory, W.X.; Muell, M.R.; Summers, K.; Brown, J.L. Phylogenomic reconstruction of the Neotropical poison frogs (Dendrobatidae) and their conservation. Diversity 2019, 11, 126. [CrossRef]

13. Daly, J.W. Thirty years of discovering arthropod alkaloids in amphibian skin. J. Nat. Prod. 1998, 61, 162-172. [CrossRef] [PubMed]

14. Santos, J.C.; Coloma, L.A.; Cannatella, D.C. Multiple, recurring origins of aposematism and diet specialization in poison frogs. Proc. Natl. Acad. Sci. USA 2003, 100, 12792-12797. [CrossRef] [PubMed]

15. Summers, K.; Clough, M.E. The evolution of coloration and toxicity in the poison frog family (Dendrobatidae). Proc. Natl. Acad. Sci. USA 2001, 98, 6227-6232. [CrossRef]

16. Guayasamin, J.M.; Cisneros-Heredia, D.F.; McDiarmid, R.W.; Peña, P.; Hutter, C.R. Glassfrogs of Ecuador: Diversity, evolution, and conservation. Diversity 2020, 12, 222. [CrossRef]

17. Castroviejo-Fisher, S.; Guayasamin, J.M.; Gonzalez-Voyer, A.; Vila, C. Neotropical diversification seen through glassfrogs. J. Biogeogr. 2014, 41, 66-80. [CrossRef]

18. Delia, J.; Bravo-Valencia, L.; Warkentin, K.M. Patterns of parental care in Neotropical glassfrogs: Fieldwork alters hypotheses of sex-role evolution. J. Evol. Biol. 2017, 30, 898-914. [CrossRef]

19. Delia, J.R.J.; Ramirez-Bautista, A.; Summers, K. Parents adjust care in response to weather conditions and egg dehydration in a Neotropical glassfrog. Behav. Ecol. Sociobiol. 2013, 67, 557-569. [CrossRef]

20. Hutter, C.R.; Guayasamin, J.M.; Wiens, J.J. Explaining Andean megadiversity: The evolutionary and ecological causes of glassfrog elevational richness patterns. Ecol. Lett. 2013, 16, 1135-1144. [CrossRef]

21. Ramirez, J.P.; Jaramillo, C.A.; Lindquist, E.D.; Crawford, A.J.; Ibáñez, R. Recent and rapid radiation of the highly endangered Harlequin frogs (Atelopus) into Central America inferred from mitochondrial DNA sequences. Diversity 2020, 12, 360. [CrossRef]

22. Stuart, S.N.; Chanson, J.S.; Cox, N.A.; Young, B.E.; Rodrigues, A.S.L.; Fischman, D.L.; Waller, R.W. Status and trends of amphibian declines and extinctions worldwide. Science 2004, 306, 1783-1786. [CrossRef] [PubMed]

23. Böhm, M.; Collen, B.; Baillie, J.E.M.; Bowles, P.; Chanson, J.; Cox, N.; Hammerson, G.; Hoffmann, M.; Livingstone, S.R.; Ram, M.; et al. The conservation status of the world's reptiles. Biol. Conserv. 2013, 157, 372-385. [CrossRef]

24. Cacciali, P.; Buongermini, E.; Kohler, G. Barcoding analysis of Paraguayan Squamata. Diversity 2019, 11, 152. [CrossRef]

25. Rabosky, D.L.; von May, R.; Grundler, M.C.; Rabosky, A.R.D. The western Amazonian richness gradient for squamate reptiles: Are there really fewer snakes and lizards in southwestern Amazonian lowlands? Diversity 2019, 11, 199. [CrossRef]

26. Birskis-Barros, I.; Alencar, L.R.V.; Prado, P.I.; Böhm, M.; Martins, M. Ecological and conservation correlates of rarity in New World pitvipers. Diversity 2019, 11, 147. [CrossRef]

27. Phillips, J.G.; Burton, S.E.; Womack, M.M.; Pulver, E.; Nicholson, K.E. Biogeography, systematics, and ecomorphology of Pacific Island anoles. Diversity 2019, 11, 141. [CrossRef]

28. Zumbado-Ulate, H.; Nelson, K.N.; Garcia-Rodriguez, A.; Chaves, G.; Arias, E.; Bolanos, F.; Whitfield, S.M.; Searle, C.L. Endemic infection of Batrachochytrium dendrobatidis in Costa Rica: Implications for amphibian conservation at regional and species Level. Diversity 2019, 11, 129. [CrossRef]

29. Scheele, B.; Pasmans, F.; Skerratt, L.F.; Berger, L.; Martel, A.; Beukema, W.; Acevedo, A.A.; Burrowes, P.A.; Carvalho, T.; Catenazzi, A.; et al. Amphibian fungal panzootic causes catastrophic and ongoing loss of biodiversity. Science 2019, 363, 1459-1463. [CrossRef]

30. Bornschein, M.R.; Pie, M.R.; Teixeira, L. Conservation status of Brachycephalus toadlets (Anura: Brachycephalidae) from the Brazilian Atlantic rainforest. Diversity 2019, 11, 150. [CrossRef]

31. Mayani-Parás, F.; Botello, F.; Castañeda, S.; Sánchez-Cordero, V. Impact of habitat loss and mining on the distribution of endemic species of amphibians and reptiles in Mexico. Diversity 2019, 11, 210. [CrossRef]

32. Löwenberg-Neto, P. Neotropical region: A shapefile of Morrone's (2014) biogeographical regionalisation. Zootaxa 2014, $3802,300$. [CrossRef] [PubMed] 